\title{
Myosin-I Isozymes in Neonatal Rodent Auditory and Vestibular Epithelia
}

\author{
Rachel A. Dumont, ${ }^{1}$ Yi-dong Zhao, ${ }^{2}$ Jeffrey R. Holt, ${ }^{3}$ Martin Bähler, ${ }^{4}$ and Peter G. Gillespie ${ }^{1}$ \\ ${ }^{1}$ Oregon Hearing Research Center and Vollum Institute, Oregon Health E Science University, Portland, OR 97201, USA \\ ${ }^{2}$ Department of Physiology, Johns Hopkins University, Baltimore MD 21205, USA \\ ${ }^{3}$ Harvard Medical School and Massachusetts General Hospital, Boston MA 02114, USA \\ ${ }^{4}$ Institut für Allgemeine Zoologie und Genetik, Westfälische Wilhelms-Universität Münster, Münster, Germany
}

Received: 22 October 2001; Accepted: 18 December 2001; Online publication: 27 February 2002

\section{ABSTRACT}

Myosin isozymes are essential for hair cells, the sensory cells of the inner ear. Because a myosin-I subfamily member may mediate adaptation of mechanoelectrical transduction, we examined expression of all eight myosin-I isozymes in rodent auditory and vestibular epithelia. Using RT-PCR, we found prominent expression of three isozymes, Myolb (also known as myosin-I $\alpha$ or myr 1 ), Myolc (myosin-I $\beta$ or myr 2), and Myole (myr 3). By contrast, Myola (brush-border myosin-I), Myold (myosin $1 \gamma$ or myr 4 ), Myo1f, Myo1g, and Myo1h were less readily amplified. Because sequence analysis demonstrated that the RTPCR products encoded the appropriate isozymes, this represents the first demonstration of expression of all eight mouse myosin-I genes. Using immunocytochemistry with isozyme-selective antibodies, we found that Myolb was located at apical surfaces of supporting cells that surround hair cells in auditory epithelia of postnatal rats. In vestibular epithelia, Myolb was present in a ring within the apical pole of the hair cell. In both cases, expression was prominent only immediately after birth. Myole was found in hair cells of the auditory and vestibular epithelia; this isozyme was enriched in the cuticular plate, the actin meshwork that anchors the stereocilia. Myolc was found in

Correspondence to: Peter G. Gillespie, Ph.D. • Oregon Hearing Research Center \& Vollum Institute • L335A / Oregon Health \& Science University - 3181 SW Sam Jackson Park Road - Portland, OR 97201. Telephone: (503) 494-2936; fax: (503) 494-2976; email: gillespp@ohsu.edu hair-cell stereocilia, concentrated towards their tips; we confirmed this localization by using adenovirus vectors to direct expression of a GFP-Myolc tail fusion protein; this fusion protein localized to plasma membranes, often concentrating at stereociliary tips. Myo1c therefore remains the myosin isozyme best localized to carry out transducer adaptation.

Keywords: myosin, hair cells, stereocilia, adaptation, transduction

\section{INTRODUCTION}

Hair cells, the sensory cells of the auditory and vestibular systems, rely on actin-rich structures for mechanoelectrical and electromechanical transduction (Gillespie et al. 1996). The mechanically sensitive hair, bundle is largely made up of stereocilia, which consist of highly crosslinked, parallel actin filaments enveloped by plasma membrane. Stereocilia insert into and are anchored by the cuticular plate, a meshwork of randomly oriented actin filaments (DeRosier and Tilney 1989). Circumferential actin rings in hair cells and supporting cells may contribute to the stiffness of the apical epithelial surface (Drenckhahn et al. 1991). Finally, cortical actin filaments are essential for the specialized contractile activity of the outer hair cell's lateral wall (Holley et al. 1992).

The prominence of actin-containing structures within hair cells suggests that motor proteins that generate force along actin will also prove essential for proper function of these sensory cells. Indeed, mu- 
TABLE 1

\begin{tabular}{|c|c|c|c|}
\hline \multicolumn{4}{|c|}{ Myosin-I nomenclature } \\
\hline Name & Other names & GenBank accession numbers & PCR primers \\
\hline Myo1a & $\begin{array}{l}\text { Brush-border } \\
\text { Myosin-I }\end{array}$ & AF009960 & $\begin{array}{l}\text { (+) 5'-CTACAGCAGGTGTTCATAG-3' } \\
\text { (-) 5'-TGGAAACAAGGACTTCAGG-3' }\end{array}$ \\
\hline Myo1b & $\begin{array}{l}\text { Myosin-l } \alpha \\
\text { myr } 1 ; \text { MI-130K }\end{array}$ & NM_010863 & $\begin{array}{l}\text { (+) 5'-CAAGAGGTGAAAGAAACTTCG-3' } \\
\text { (-) 5'-TCTTCGCTTCAACTGTTCGG-3' }\end{array}$ \\
\hline Myo1c & $\begin{array}{l}\text { Myosin-l } \beta \\
\text { myr 2; MI-110K }\end{array}$ & NM_008659 & $\begin{array}{l}\text { (+) 5'-AGTCTCTGTCAATCCCTACC-3' } \\
\text { (-) 5'-GGAGGTAACTGAGAATGTGG-3' }\end{array}$ \\
\hline Myo1d & Myosin-I $\gamma ;$ myr 4 & BF016443 & $\begin{array}{l}\text { (+) 5'-GCAGAAGTCACTCTCATCG-3' } \\
\text { (-) 5'-CTTGGCAAAGGCGTCTCTG-3' }\end{array}$ \\
\hline Myo1e & Myr 3 & $\begin{array}{l}\text { AA250515; BF016461; } \\
\text { BG076620; BG086565 }\end{array}$ & $\begin{array}{l}\text { (+) 5'-CAAGAAGCCTAAAGACTGGG-3' } \\
\text { (-) 5'-TCCTCCTCTCCTTCTTGTTC-3' }\end{array}$ \\
\hline Myo1f & & NM_008660 & $\begin{array}{l}\text { (+) 5'-CTACATACCATCCCTCACC-3' } \\
\text { (-) 5'-TCCCCCACCAGACACCTTG-3' }\end{array}$ \\
\hline Myo1g & & $\begin{array}{l}\text { BE848707; } \\
\text { AW986090; }\end{array}$ & $\begin{array}{l}\text { (+) 5'-ACTAAAGGCACTTCGGGAG-3' } \\
\text { (-) 5'-GGCTCCACAGAAATGAGGC-3' }\end{array}$ \\
\hline Myo1h & & AK014505 & $\begin{array}{l}\text { (+) 5'-AGTTCGTAGTGCTTGTGAGG-3' } \\
\text { (-) 5'-GTATGCTGACCTCTGTGTG-3' }\end{array}$ \\
\hline
\end{tabular}

${ }^{a}$ Note that there is confusion in the literature and databases between Myo1c and Myo1e. We use the mouse names for the rat isozymes as well. GenBank accession numbers refer to complete sequences (Myo1a, Myo1b, Myo1c, Myo1f) or ESTs used in characterization of other isozymes (Myo1d, Myo1e, Myo1g, Myo1h).

tations in at least four myosin genes of humans or mice-MYH9, MYO6, MYO 7a, and MYO15-lead to deafness and vestibular dysfunction (Avraham et al. 1995; Gibson et al. 1995; Probst et al. 1998; Lalwani et al. 2000). Other myosin isozymes may be necessary for hair cells; indeed, the full complement of myosin isozymes required by hair cells remains unknown. An RT-PCR screen identified 13 myosin isozymes, from six separate classes, in the frog saccule (Sole et al. 1994). Other myosin isozymes known to be expressed in rodent hair-cell epithelia were not detected in this PCR screen, however, including Myo15 (Probst et al. 1998) and Myolf (Crozet et al. 1997). Other members of the myosin-I class were, however, prominent in this screen.

Myosin-I isozymes are $100-130 \mathrm{kD}$ and share several structural features, including an actin- and ATPbinding head domain, a neck region containing one to six calmodulin-binding IQ domains, and a highly basic tail that mediates interaction with acidic phospholipids (Coluccio 1997). One member of this class, myosin-1c (Myolc; formerly known as myosin$1 \beta$; see Table 1 and nomenclature note in Materials and Methods), may facilitate adaptation of mechanoelectrical transduction (Gillespie and Corey 1997). Localization and biochemical data support this suggestion in the bullfrog sacculus. Myolc is located at stereociliary tips, near the end of tip links (Gillespie et al. 1993; Hasson et al. 1997; Garcia et al. 1998; Steyger et al. 1998). A $120-k D$ protein that can be photoaffinity labeled with radioactive nucleotides has pharmacological properties consistent with those of the adaptation motor (Gillespie et al. 1993; Yamoah and Gillespie 1996; Burlacu et al. 1997); the strongest candidate for this photolabeled protein is Myolc. Finally, adaptation can be blocked by a mutant-selective inhibitor when a mutant Myo1c is expressed in mouse hair cells (Holt et al. 2002).

Because of the powerful transgenic and gene-targeting techniques available for analysis of gene function in mice, rodents are more amenable to testing the role of specific proteins in hair-cell function. In addition, adenovirus-mediated gene transfection has proven successful in mouse hair cells (Holt et al. 1999). Fortunately, mechanoelectrical transduction in mouse vestibular hair cells resembles closely that in more thoroughly characterized frog hair cells (Holt et al. 1997). These techniques should in the future permit more rigorous testing of hypotheses for roles for myosin molecules in these cells.

Although Myo1c is the best candidate for the frog saccule adaptation motor, other myosin-I isozymes might contribute to the motor. Therefore, we sought to document the locations of members of the myosin-I family in the rodent auditory and vestibular systems. We found that three myosin-I isozymes, Myolb, Myolc, and Myole, are expressed at birth in cochlea and vestibular organs, but only Myolc remains at a high level subsequently. Localization at stereociliary tips confirms that Myo1c is a strong candidate for the adaptation-motor myosin of rodent vestibular hair cells.

\section{METHODS}

\section{Myosin nomenclature}

Nomenclature for myosin-I isozymes is confusing and contradictory (Berg et al. 2001). Although several 
names have been used for each of the myosin isozymes examined here, we adopt here the official Human Genome Organization (HUGO) names (http://www.gene.ucl.ac.uk/nomenclature/; Table 1). This nomenclature has been adopted by almost all researchers studying vertebrate myosin-I isozymes (Gillespie et al. 2001).

\section{RT-PCR}

Purified total RNA (RNeasy Kit, Qiagen, Valencia, CA) from P3-P12 mouse utricles was primed using random hexamers and reverse-transcribed (ThermoScript RT-PCR System, Life Technologies, Carlsbad, $\mathrm{CA}$ ). Isozyme-specific primers (Table 1) were used in PCR reactions to detect each myosin-I. The amplification protocol with Taq polymerase (Promega, Madison, WI) comprised $4 \mathrm{~min}$ at $94^{\circ} \mathrm{C}, 25-30$ cycles of $60 \mathrm{~s}$ at $94^{\circ} \mathrm{C}, 30 \mathrm{~s}$ at $50^{\circ} \mathrm{C}, 50 \mathrm{~s}$ at $72^{\circ} \mathrm{C}$, and a final $10 \mathrm{~min}$ at $72^{\circ} \mathrm{C}$. The amplification protocol with a proofreading polymerase (Proofstart, Qiagen) comprised $5 \mathrm{~min}$ at $95^{\circ} \mathrm{C}, 35$ cycles of $60 \mathrm{~s}$ at $94^{\circ} \mathrm{C}, 30 \mathrm{~s}$ at $50^{\circ} \mathrm{C}, 50 \mathrm{~s}$ at $72^{\circ} \mathrm{C}$, and a final $10 \mathrm{~min}$ at $72^{\circ} \mathrm{C}$. PCR products were cloned into the pCR2.1-TOPO vector (TOPO Cloning, Invitrogen, Carlsbad, CA). Cloned PCR products were sequenced using the vector M13 reverse primer or $\mathrm{T} 7$ promoter primer.

\section{Hair-bundle purification}

This method was similar to those described for frog saccular and utricular hair bundles (Gillespie and Hudspeth 1991; Steyger et al. 1998). Rat or mouse vestibular organs were dissected in minimal essential medium (MEM, Life Technologies), which was supplemented with $25 \mathrm{mM}$ HEPES $\mathrm{pH} 7.5$, and were adhered to a coverslip coated with Cell-Tak (Becton Dickinson Labware, Bedford, MA). Molten lowmelting-point agarose $\left(3 \%-4 \%\right.$ in MEM) at $37^{\circ} \mathrm{C}$ was used to flood the coverslip, then was allowed to set to a firm gel by cooling to $4^{\circ} \mathrm{C}$. Bundles were severed from hair-cell bodies by shearing the agarose relative to the coverslip. Under dark-field illumination, bundles were visualized and excised in a plug of agarose.

\section{Protein purification}

Production of rat Myolc in baculovirus has already been described (Gillespie et al. 1999); the resulting protein has an N-terminal hexahistidine tag, which is used for purification. Myolb (b splice form) was introduced into the pVL1392 baculovirus transfer vector; Myole was introduced into pVL1393. Both constructs encoded full-length myosin molecules without epitope tags. Recombinant baculoviruses were produced using standard techniques (O'Reilly et al. 1994). Myo1b, Myolc, and Myole were expressed by infecting Sf9 insect cells with recombinant baculoviruses. In a typical experiment, $4-8 \times 10^{8} \mathrm{Sf9}$ cells in $400 \mathrm{~mL}$ of Grace's medium (Life Technologies) containing $3.3 \mathrm{mg} / \mathrm{mL}$ lactalbumin hydrolysate, $3.3 \mathrm{mg} / \mathrm{mL}$ yeastolate, $20 \mu \mathrm{g} / \mathrm{mL}$ gentamicin, $0.1 \%$ Pluronic F-68, and $10 \%$ fetal calf serum were infected with myosin and calmodulin viruses at a multiplicity of infection of 4 and 2, respectively. After $48 \mathrm{~h}$ at $27^{\circ} \mathrm{C}$, the cells were centrifuged at $1500 \mathrm{~g}$, washed with PBS, and recentrifuged. Pelleted cells were stored at $-80^{\circ} \mathrm{C}$ prior to use. For purification, cells were thawed, resuspended with purification buffer $(25 \mathrm{mM}$ Tris $\mathrm{pH} 7.5,0.5 \mathrm{mM} \mathrm{MgCl}_{2}, 0.5 \mathrm{mM}$ EGTA, $2.5 \mathrm{mM}$ 2mercaptoethanol, $0.2 \mathrm{mM}$ PMSF, $1 \mu \mathrm{M}$ leupeptin, 1 $\mu \mathrm{M}$ pepstatin), and lysed by passage through 22 gauge and 25 gauge needles. The lysate was adjusted to 300 $\mathrm{mM} \mathrm{NaCl}$ and $1 \mathrm{mM}$ ATP and was centrifuged at $400,000 \mathrm{~g}$ for $30 \mathrm{~min}$. Myolc was purified by $\mathrm{Ni}^{2+}-$ NTA affinity chromatography and gel filtration as described (Gillespie et al. 1999).

For other isozymes, the supernatant was diluted to a $\mathrm{NaCl}$ concentration of $100 \mathrm{mM}$ (Myo1b) or $150 \mathrm{mM}$ (Myole) and was loaded on to a HiTrap SP cationexchange column (Amersham Pharmacia Biotech). After washing with isolation solution containing the same $\mathrm{NaCl}$ concentration, bound proteins were eluted with a salt gradient. Myosin-containing fractions were identified by immunoblotting. Purified actin, stabilized with an equimolar concentration of unlabeled phalloidin, was added to a final concentration of $5 \mu \mathrm{M}$; after incubation on ice for $30 \mathrm{~min}$, the solution was centrifuged at 400,000 $\mathrm{g}$ for $30 \mathrm{~min}$. After resuspending the actomyosin pellet with $1 \mathrm{mM}$ ATP, $50 \mathrm{mM} \mathrm{KCl}, 1 \mathrm{mM} \mathrm{MgCl} 2,0.1 \mathrm{mM}$ EGTA, and $15 \mathrm{mM}$ HEPES at $\mathrm{pH} 7.5$, the solution was recentrifuged at $400,000 \mathrm{~g}$ for $30 \mathrm{~min}$. Myolb or Myole were found in the supernatant fluid at $25-50 \%$ purity; we estimated their concentrations by densitometry using BSA as a standard.

\section{Protein immunoblots}

For quantitation of myosin-isozyme levels in rat innerear organs, both vestibular organs and segments of cochlea were dissected from 3-4-day-old pups, treated with SDS-containing sample buffer, and analyzed by protein immunoblotting as described (Gillespie and Gillespie 1997; Hasson et al. 1997). Standards of partially purified (Myolb, Myole) or purified (Myolc; Gillespie et al. 1999) myosin were included on the immunoblots for quantitation. Myolc in mouse hair bundles and residual maculae (the epithelium remaining after hair-bundle isolation) was measured similarly; actin was detected using an IgM monoclonal antibody (N350; Amersham Pharmacia 
Biotech, Piscataway, NJ) that recognizes all actin isoforms. Purified platelet actin (Cytoskeleton, Denver, $\mathrm{CO})$, a mixture of $85 \% \beta$-actin and $15 \% \gamma$-actin, was used as a standard for immunoblotting.

\section{Myosin antibodies}

Affinity-purified antibodies against Myo1b (Tü 30), Myold (Tü 12), and Myole (FML 6) have been described previously (Ruppert et al. 1993; Bähler et al. 1994; Stoffler et al. 1995). Myolc antisera directed against either the C-terminal $15-\mathrm{kD}$ or $30-\mathrm{kD}$ domain of rat Myolc were produced for this study. Using primers for rat Myolc (15 kD forward-CAGGGA TCCAAGCCTCGTTCCCGGCAG, $30 \mathrm{kD}$ forward-CAGGGATCCATTTTGCGTCATGCACCCC, reverse CAGTGCAAGCTTTCATCACCGAGAATTCAGCC) that introduced Bam $\mathrm{H} \mathrm{I}$ and Hind III restriction-endonuclease sites, we amplified by PCR segments of rat Myo1c cDNA corresponding to amino acids $899-1028$ or $760-1028$ of rat Myolc. Fragments were cloned into pET-28a $(+)$ (Novagen, Madison, WI), introducing a hexahistidine tag. Following expression in E. coli strain BL21(DE3), 15-kD or $30-\mathrm{kD}$ fragments $\left(\mathrm{His}_{6}-\mathrm{R} 15\right.$ and $\left.\mathrm{His}_{6}-\mathrm{R} 30\right)$ were purified on $\mathrm{Ni}^{2+}-\mathrm{NTA}$ (Qiagen) in the presence of 6 $\mathrm{M}$ urea. After dialysis against PBS, insoluble $\mathrm{His}_{6}-\mathrm{R} 15$ or $\mathrm{His}_{6}-\mathrm{R} 30$ were used separately to immunize rabbits (Covance Research Products, Denver, PA).

The R2652 antiserum, raised against $\mathrm{His}_{6}-\mathrm{R} 15$, was affinity purified against the C-terminal $30-\mathrm{kD}$ domain of Myo1c, fused to glutathione-S-transferase (GSTR30). To generate GST-R30, PCR was used to amplify a cDNA fragment corresponding to amino acids 7601028 of rat Myolc cDNA using the primers described above. The PCR product was cloned into the pGEX6p-l vector (Amersham Pharmacia Biotech). GST-R30 was expressed in BL21(DE3) cells, extracted from the cell pellet with $6 \mathrm{M}$ urea, dialyzed against $2 \mathrm{M}$ urea/ PBS, and purified on a glutathione-agarose column in the presence of $2 \mathrm{M}$ urea. After elution with $2.5 \mathrm{M}$ urea, $15 \mathrm{mM}$ glutathione, $5 \mathrm{mM}$ DTT, and $1.5 \%$ octyl glucoside in PBS, the fusion protein was dialyzed against $2 \mathrm{M}$ urea/PBS, then coupled to Affi-Gel 10 (Bio-Rad, Hercules, CA) in the presence of $2 \mathrm{M}$ urea. R2652 antiserum was passed over this column; after washing, the column was sequentially eluted with 100 $\mathrm{mM}$ glycine (pH 2.5) and $100 \mathrm{mM}$ 3-[cyclohexylamino]-1-propanesulfonic acid ( $\mathrm{pH} 11)$. Eluted antibodies were dialyzed against PBS prior to use.

The R2695 antiserum, raised against $\mathrm{His}_{6}-\mathrm{R} 30$, was affinity purified as above against a baculovirusexpressed tail construct incorporating amino acids 701-1028 of rat Myo1c (J. Cyr, R.A.D., and P.G.G, unpublished data), which was coexpressed with calmodulin and coupled to CNBr-Sepharose (Amersham Pharmacia Biotech).

\section{Immunofluorescence microscopy}

Vestibular epithelia and segments of cochlea were dissected from P1 (i.e., one-day postnatal), P7, P14, or P21 rat pups, fixed with $3 \%$ formaldehyde in MEM (Life Technologies), and permeabilized with $0.2 \%$ saponin. Following blocking and permeabilization with $5 \%$ goat serum, $1 \%$ BSA, and $0.1 \%$ saponin for $60 \mathrm{~min}$, tissues were incubated overnight at $4^{\circ} \mathrm{C}$ with primary antibodies in $1 \%$ goat serum, $1 \%$ BSA, and $0.1 \%$ saponin. After washing, biotin-conjugated goat antirabbit antibodies $(6 \mu \mathrm{g} / \mathrm{mL}$; Vector Laboratories, Burlingame, CA) were applied for $60 \mathrm{~min}$ at room temperature. After washing, bound antibodies were detected by incubation with $5 \mu \mathrm{g} / \mathrm{mL}$ Cy5-streptavidin (Jackson ImmunoResearch Labs, WestGrove, PA) and $0.4 \mu \mathrm{M}$ FITC-phalloidin (Sigma-Aldrich, St.Louis, MO) for $60 \mathrm{~min}$. For some experiments, detection with the R2652 antiserum against Myolc employed an amplification method (Adams 1992) between the latter two steps. Following the secondary antibody incubation, tissues were treated with HRP-labeled streptavidin. Treatment with biotinylated tyramine and $\mathrm{H}_{2} \mathrm{O}_{2}$ permitted deposition of polymerized biotinylated tyramine, which was detected with Cy5streptavidin. As above, tissues were counterstained with FITC-phalloidin. Bound antibodies were observed using Zeiss LSM 410 or Bio-Rad MRC 1024 confocal microscopes and a $60 \mathrm{X}$ or $100 \mathrm{X}, 1.4 \mathrm{nu}-$ merical aperture oil-immersion lens.

\section{Adenovirus production and use}

Replication-deficient (E1a/b deleted) recombinant adenovirus was generated as previously described (Holt et al. 1999). For this study, DNA encoding the enhanced green fluorescent protein (EGFP) was fused in frame to DNA encoding the tail portion of Myolc (residues 698-1028) and was inserted into the multiple cloning site of an adenovirus shuttle plasmid immediately downstream of the cytomegalovirus promoter. The shuttle plasmid was cotransfected with a plasmid that carried the adenovirus genome into BJ5183 cells to yield pAdGFP::T698. The plasmid was transfected into and virus was serially amplified in E1-transformed HEK 293 cells. The virus was then purified by density centrifugation on $\mathrm{CsCl}$ gradients to yield a stock titer of $4 \times 10^{10}$ particles/ml of pAdGFP::T698.

The sensory epithelia of P2 mice were removed and grown in organotypic culture for 36-48 h as previously described (Holt et al. 1997, 1999). Epithelia were exposed to $4 \times 10^{8}$ particles $/ \mathrm{ml}$ pAdGFP::T698 for $24 \mathrm{~h}$. Twelve to $24 \mathrm{~h}$ later, epithelia were fixed and counterstained with rhodamine-conjugated phalloidin. The samples were imaged on a Bio-Rad MRC 1024 confocal microscope. 


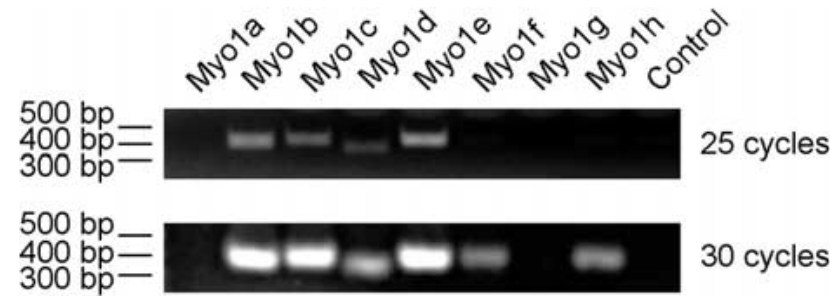

Fig. 1. RT-PCR analysis of mouse utricle myosin-I mRNA. Total RNA was isolated from mouse utricles and CDNA was prepared by reverse transcription. Isozyme-specific primers were used to amplify cDNAs corresponding to each myosin-I. The negative control substituted water for CDNA; rat PMCA2 primers were used for a positive control reaction (not shown). PCR was carried out using Taq polymerase for 25 cycles (top) or 30 cycles (bottom). Although we did not observe Myo1a and Myo1g products in these reactions, they were detected in several other experiments.

\section{RESULTS}

\section{RT-PCR}

To identify myosin-I isozymes in rodent inner ears, we examined mRNA expression using RT-PCR. The human genome contains eight myosin-I genes in four subgroups (Berg et al. 2001; see Table 1); we assumed that the mouse genome contains orthologs for each isozyme. Full-length sequences for four of these isozymes (Myo1a, Myolb, Myo1c, and Myolf) have been cloned from mouse tissues (Sherr et al. 1993; Crozet et al. 1997; Skowron and Mooseker 1999). To identify mouse DNA segments encoding the other four myosin isozymes, we used the BLAST search algorithm (Altschul et al. 1990) to search the database of mouse expressed sequence tags (ESTs). Using rat (Myold, Myole) or human (Myolg, Myolh) query sequences, we identified at least one mouse EST for each myosinI not already cloned from mouse (Table 1). In some cases, we used overlapping ESTs to construct a partial contiguous sequence. Using these sequences, we designed primers with similar melting temperatures that amplified similar-sized products from each of the myosin-I isozymes under identical conditions, then demonstrated using control tissues that each primer pair successfully amplifies the appropriate sequence (not shown). To ensure that we did not amplify genomic DNA, we confirmed from the partially complete mouse genome sequence (http://mouse. ensembl.org/Mus_musculus/blastview) for Myolc, Myold, Myolf, and Myolg that our PCR products spanned introns; genomic products would have been substantially larger than the products we predicted and detected. Although genomic sequence is not yet available for Myola, Myolb, Myole, or Myolh, the regions amplified span introns in the homologous human sequences (http://www.ncbi. nlm.nih.gov/ genome/seq/HsBlast.html). If the intron-exon boundaries are conserved between mouse and hu- man, as is likely, genomic products should also be distinguishable from cDNA products in these PCR reactions.

Using these isozyme-selective primers, we carried out RT-PCR on cDNA derived from neonatal mouse utricle. In 25-cycle reactions with Taq polymerase, we observed prominent PCR products for Myolb, Myolc, and Myole (Fig. 1). Extension of the PCR to 30 or more cycles reproducibly led to successful amplification of Myold and Myo1f, and sometimes amplified Myola, Myolg, and Myo1h. Although not quantitative, these results suggest that Myolb, Myo1c, and Myole are expressed at higher levels than are other myosin-I isozymes.

With one exception (Myola), we amplified myosinI fragments for sequencing in two separate experiments, one with Taq polymerase and one with a proofreading polymerase (Fig. 2). Although Myola was amplified with only Taq polymerase, the sequence we obtained was identical to that in GenBank (AF009960). For all other isozymes, we obtained identical sequences with both polymerases from different cDNA preparations. Although amplified products from Myolc were identical to the corresponding mouse sequence in GenBank (NM_008659), Myolb and Myolf products differed significantly from mouse sequences in GenBank. Our Myolb sequence differed in 8 positions from that of the Genbank entry (NM_010863), producing substantial changes in the predicted amino acid sequence. Five nucleotide differences and three inserted nucleotides between nucleotides 1107 and 1148 in the GenBank sequence predict a very different amino acid sequence for NM_010863 (IELNEKFASRPASVK for residues 304-318) than for our entry (NELKEICELTSIDQ). The amino acid sequence of rat Myolb (X68199) is identical to our predicted sequence in this region, however, suggesting that our sequence is representative. Our Myolf sequence differed in 16 positions from that of the GenBank entry (NM_008660), producing five changes in the predicted amino acid sequence. Only one of the amino acid changes was conservative. Two of the nucleotide changes that did not alter the amino acid sequence were found in at least one EST but not others (nucleotides 206 and 215 of NM_008660), suggesting that they are polymorphisms. All of the remaining 14 discrepant nucleotides where our sequence differed from NM_008660 were identical to the corresponding nucleotides in all other ESTs we found (not shown), suggesting that our sequence is representative.

Other than EST sequences, no mouse nucleotide sequences are available for Myold, Myole, Myolg, and Myolh. At the amino acid level, our Myold product was $99 \%$ identical to a mouse Myold aminoacid sequence (myosin-I $\gamma$; C45438) and 99\% 


\section{Myo1b}

MMyo 1b RT-PCR mMyo 1b

rMyolb

mMyo 1b RT-PCR

mMyoltb
rMyolb

MMyo 1b RT-PCR mMyolb

myoto

MMyo 1b RT-PCR

mMyolb

Myo1b

MMyo 1b RT-PCR

mMyo1b

rMyolb

\section{Myo1e}

mMyole RT-PCR mMyole ESTs

rMyole

mMyole RT-PCR mMyole ESTs

rMyole

mMyole RT-PCR mMyole ESTS

rMyole

mMyole RT-PCR mMyole ESTS

rMyole

mMyole RT-PCR mMyole ESTs rMyole

\section{Myo1g}

MMyo ig RT-PCR mMyolg ESTS

hMyolg

mMyo ig RT-PCR mMyoig ESTs

hMyolg

mMyo 1g RT-PCR mMyo1g ESTs

hMyolg

mMyo ig RT-PCR mMyolg ESTs

hMyolg

mMyo ig RT-PCR mMyolg ESTs

hMyols

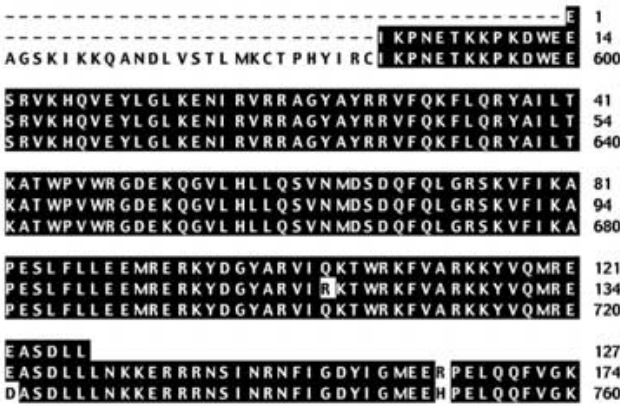

Myo1f

MMyo if RT-PCR

mMyolf

hMyolf

mMyo if RT-PCR

mMyolf

hMyolf

MMyo if RT-PCR

mMyo if

hMyolf

MMyo if RT-PCR

mMyo 1

hMyoif

MMyo if RT-PCR

mMyo $1 f$

hMyolf

\section{Myo1h}

MMyo 1h RT-PCR mMYo ith ESTS

hMyoth

mMyo 1h RT-PCR mMYo th ESTs

hMyolh

MMyo ih RT-PCR mMYoth ESTS

hMyoith

MMyo 1h RT-PCR MMYOIH ESTS hMyolh

MMyo ih RT-PCA mMyoth ESTs hMyoith
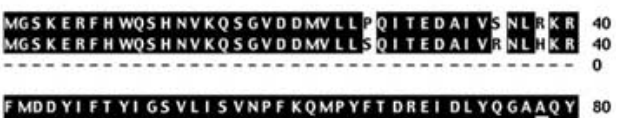
MDDYI FT YI GS VLI S VNPF KQMPYFT DREI DLYQGAVDY 80 -DDYIFTYI GSVLI S VNPF KOMPYFT DREI DLYOGAAOY 38 ENPP HI YALT DN MYRNMLI DCENQCVI I SGESGAGKT VAA 126 EPP HI YALTDNMYRNMLI DCENOCVI I SGESGAGKTVAA 12 ENPPHI YALI DNMYRNMLI DCENOCVI I SGESGAGKT VAA 78 KYI MGYI SKVS GGGDKYOHVKDI I LOSNPL LEAFGNAKTV KYI MGYISKVSGGGE KVQHVKDI I L OS NPLLEAFGNAKT V

TNNNSSRF GKYF EI QF SRGGEPDGGKI SNFL LEKS RVVMO 20 RNNNSSRF GKYFEI OFSRGGEPDGGKI SNFLLEKSRVVMO

Fig. 2. Sequence analysis of mouse myosin-I transcripts. Conceptual translations of RT-PCR products were aligned with appropriate database sequences when significant differences were found or when mouse orthologs have not been previously reported. Myo1b, alignment with mouse Myo1b (myosin-l $\alpha$; NM_010863) and rat Myo1b (myr 1; X68199). Myo1d, alignment with mouse Myo1d (myosin-I $\gamma ;$ C45438) and rat Myo1d (myr 4; X71997). Myo1e, alignment with rat Myo1e (myr 3; X74815) and contiguous sequence

identical to the predicted rat Myold sequence. Our predicted sequence for Myole was $99 \%$ identical to the predicted rat sequence; Myolg was $86 \%$ identical to the predicted human Myolg sequence. The predicted human Myolh sequence included an addi-

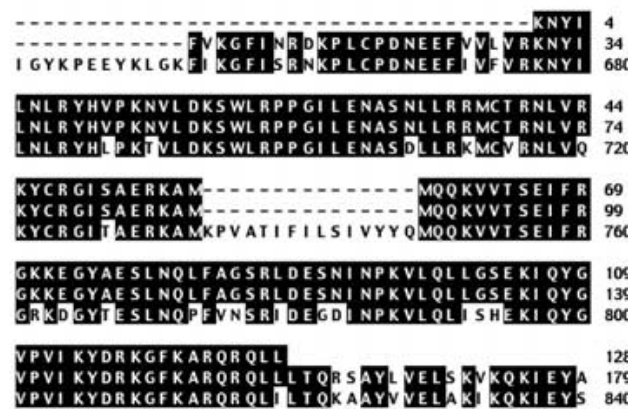

from mouse ESTs (Table 1). Myo1f, alignment with mouse Myo1f (NM_008660) and contiguous sequences from two human Myo1f sequences (U57053, erroneously labeled myosin-ID; X98411, erroneously labeled myosin-IE). Myo1g, alignment with human Myo1g (Berg et al. 2001) and contiguous sequence from mouse ESTs (Table 1). Myo1h, alignment with human Myo1h (Berg et al. 2001) and contiguous sequence from mouse ESTs (Table 1). Myo1a and Myo1c sequences exactly matched the database sequences.

tional 15 amino acids, not found in our mouse Myolh RT-PCR product or mouse ESTs; this could represent a splicing difference. Otherwise, our mouse Myolh sequence was $84 \%$ identical to the human sequence. These results represent the first simultaneous detec- 


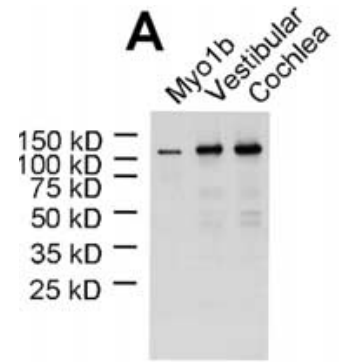

Myo1b

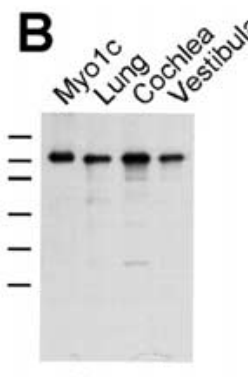

Myo1c

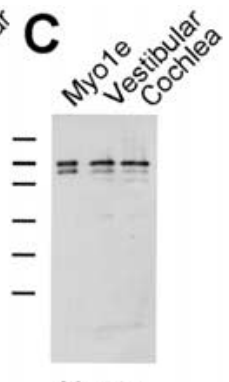

Myo1e
Fig. 3. Protein-immunoblot analysis of Myo1b, Myo1c, and Myo1e in rat cochlea and vestibular organs. Proteins were extracted from cochlea or vestibular organs (pooled saccules and utricles) with sample buffer and analyzed by immunoblotting. A. Myo1b detection; 1.9 ng Myo1b, 0.1 cochlear equivalent, and 0.5 vestibular equivalent; detection with Tü 30 antibody. B. Myo1c detection; 1.7 ng Myo1c, rat lung extract, 0.5 cochlear equivalent, and 0.7 vestibular equivalent; detection with R2652 antibody. C. Myo1e detection; 17.5 ng Myo1e, 1 cochlear equivalent, and 2 vestibular equivalents; detection with FML 6 antibody.

tion of all eight myosin-I transcripts in any species, including three (Myole, Myolg, and Myolh) previously undescribed in mouse.

\section{Protein-immunoblot quantitation}

Protein expression levels are not necessarily correlated with mRNA expression levels. We used selective antibodies, raised against rat myosin-I isozymes, to detect Myolb, Myolc, and Myole on protein immunoblots of neonatal rat cochlear and vestibular extracts (Fig. 3). A weak Myold band was observed by protein immunoblot analysis of cochlear (but not vestibular) extracts (data not shown). To quantify the abundance of each myosin isozyme in sensory epithelia, we used baculovirus vectors to express recombinant myosins and purified them to use as standards on immunoblots. In neonatal rat cochlea and vestibular organs, Myolb and Myole were each more abundant than Myo1c (Table 2), consistent with our qualitative RT-PCR data (Fig. 1).

\section{Myo1c in purified hair bundles}

Because mouse is a good model for future molecular experiments examining mechanical transduction, and Myo1c is the likely adaptation motor for the transduction apparatus, we characterized Myolc further in hair bundles of mouse utricles. To determine the abundance of Myo1c in hair bundles, we adapted the twist-off bundle-isolation method (Gillespie and Hudspeth 1991) to rat and mouse utricles and saccules. After adhering vestibular epithelia to glass coverslips and removing their otolithic membranes, we embedded them in molten agarose, chilled the

\section{TABLE 2}

Protein-immunoblot quantitation of myosin-I isozymes in rat inner-ear epithelia ${ }^{a}$

\begin{tabular}{lcc}
\hline Isozyme & Cochlea & Vestibular organs \\
\hline Myo1b & $53 \pm 14$ & $6 \pm 3$ \\
& ng/cochlea $(n=3)$ & ng/organ \\
Myo1c & $8 \pm 2$ & $2.2 \pm 0.2$ \\
Myo1e & $37 \pm 19$ & $13 \pm 4$ \\
\hline
\end{tabular}

${ }^{a}$ Neonatal (P3-P5) rat cochlea or pooled vestibular organs (saccule and utricle) were harvested and run on SDS-PAGE in parallel with recombinant myosin standards. Proteins were transferred to a blotting membrane, probed with the appropriate antibody, and visualized using chemiluminescence detection. Films were scanned and signal intensities in myosin bands were quantified with NIH Image (Scion Image version). At least three independent experiments were carried out for each isozyme.

agarose to form a stiff gel, then sheared bundles from their epithelia. With careful dissections, recoveries of bundles could exceed $90 \%$ (Fig. 4A,B), although recoveries were more typically $\sim 50 \%$. Using protein immunoblotting (Fig. 4C), we found that hair bundles contained $3.5 \pm 1.9 \mathrm{pg}$ of Myo1c per P3-P8 mouse utricle $(n=4)$. Rat vestibular bundles contained similar amounts of Myolc ( $\sim 10$ pg per organ). Because we measured $1.9 \pm 0.1 \mathrm{ng}$ of hair-bundle actin per utricle $(n=5)$, there was one Myolc molecule for approximately every 2300 actin molecules. Examining fixed, phalloidin-stained P5-P6 mouse utricles by confocal microscopy, we counted $2001 \pm 69$ $(n=3)$ hair bundles, each with $34 \pm 7(n=35)$ stereocilia. Therefore, each stereocilium contains on average $\sim 170$ molecules of Myolc, similar to estimates of 100-200 molecules of Myolc per frog stereocilium (Gillespie et al. 1993; Walker and Hudspeth 1996).

\section{Myo1b immunolocalization}

Although previous experiments had demonstrated expression of Myolb in vestibular epithelia (Solc et al. 1994), its location has not been reported. In P1 rat organ of Corti, Myolb was enriched on apical surfaces of Deiters' cells, the supporting cells that largely surround outer hair cells (Fig. 5A, Table 3). At this developmental stage, the apical extent of the Deiters' cells was relatively large, permitting easy identification. Myolb immunoreactivity was not observed in the organ of Corti of P7, P14, and P21 rats (Table 3).

In rat vestibular epithelia, localization of Myo1b was even more striking. Although the mosaic of supporting and hair cells is imperfectly formed at P1-P7, each hair cell contained within its apical surface a ring of Myo1b immunoreactivity (Fig. 5B, Table 3). These rings were clearly associated with circumferential actin belts of hair cells, rather than 

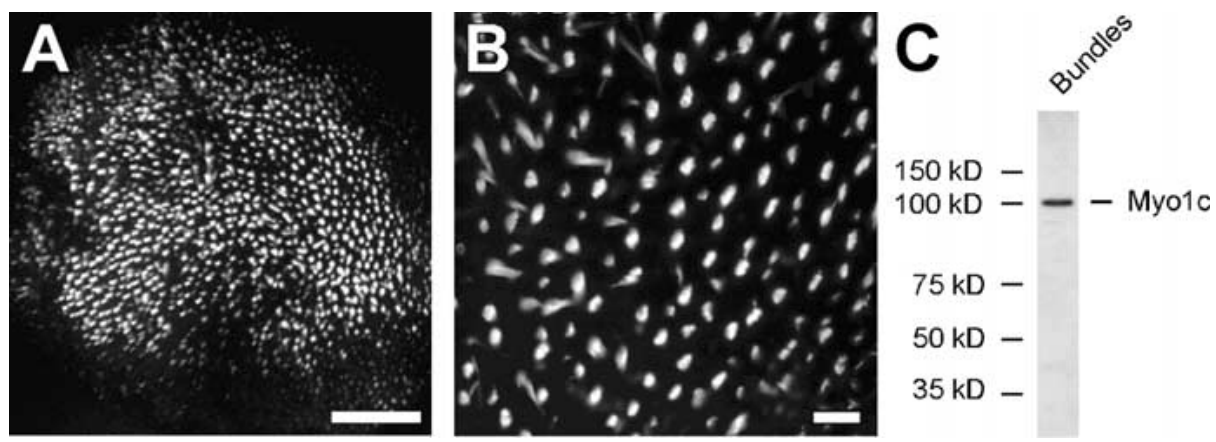

Fig. 4. Hair-bundle isolation from mouse utricle. FITC-phalloidin-labeled mouse utricular hair bundles isolated and imbedded in agarose plugs at low $(\mathbf{A})$ and high $(\mathbf{B})$ magnification. Scale bars: $A=100 \mu \mathrm{m} ; \mathrm{B}=10 \mu \mathrm{m}$. (C) Myo1c immunoblotting of purified mouse hair bundles (8 utricle equivalents) with R2652 antibody.

the pericuticular necklace (Hasson et al. 1997). In occasional P1 samples, rings were absent and the labeling was along the apical surfaces of supporting cells (data not shown), resembling the Myolb pattern in cochlea. Myolb immunoreactivity was not observed in saccule or utricle in P14 and P21 rats (Table 3).

\section{Myold immunolocalization}

Using immunofluorescence microscopy, we did not detect expression of Myold in whole-mount preparations of organ of Corti or vestibular epithelia (data not shown). Because our RT-PCR data and immunoblotting data indicated that this isozyme was expressed by these epithelia, we suspect that its expression was confined to cells that were not easily accessible to the antibody using the whole-mount immunolabeling approach, or that the epitope was masked using our conditions.

\section{Myo1e immunolocalization}

Myole was consistently observed in the cuticular plates of both cochlear and vestibular hair cells (Fig. 5C,D, Table 3). Myole levels did not appear to change substantially over the P0-P21 time frame. Although cell bodies of hair cells were labeled modestly, immunoreactivity was never observed in hair bundles.

\section{Myo1c immunolocalization}

Myolc is a candidate for the adaptation motor in frog hair cells in part because of its localization near stereocilia tips (Gillespie et al. 1993). We therefore used immunocytochemistry to determine whether localization of rodent Myolc was similar. Because Myo1c was difficult to detect using conventional immunofluorescence methodology, we used in situ amplification with the biotinylated-tyramine method to gain sufficient sensitivity (Adams 1992). Using the R2652 antibody and this method, we observed Myolc in hair bundles of neonatal organ of Corti (Fig. 6A-D) and vestibular (Fig. 6E-J) epithelia. In the organ of Corti, Myolc was present in both inner and outer hair cells, with relatively strong labeling in the cuticular plate and apparently uniform labeling in stereocilia. In vestibular hair cells, Myolc was most concentrated at the stereociliary tips. Because the shortest stereocilia of rodent vestibular hair bundles are much shorter than the longest stereocilia, bright labeling often appeared to extend down to near the cuticular plate. Nevertheless, bright labeling was usually asymmetric, corresponding to the beveled edge of the bundle. Relatively little immunoreactivity was observed in somas of hair cells or supporting cells. With the amplification conditions used, control antibodies produced some labeling of hair bundles; nevertheless, immunoreactivity for Myolc was always stronger than that for control antibodies and was located near stereociliary tips (Fig. 6E-H). By contrast, control labeling in bundles was always uniform. Myo1c labeling was observed in P1-P21 rats and mice (Table 3).

We confirmed these results with two additional preparations. We generated an additional antibody (R2695) against the C-terminal 30-kD domain of rat Myolc and affinity-purified it against baculovirusexpressed rat T701, a fragment of rat Myo1c spanning amino acids 701-1028, coexpressed with lightchain calmodulin. Using conventional detection methods and relatively high antibody concentrations (25 $\mu \mathrm{g} / \mathrm{mL})$, we found intense labeling of utricle and semicircular-canal hair bundles (Fig. 6I,J). The labeling pattern in the cochlea was very similar to that seen with R2652 (e.g., Fig. 6K,L). Labeling was particularly strong with unfixed, purified hair bundles. In addition, we observed significant labeling of inner and outer-hair-cell bundles and cuticular plates (not shown). Very low labeling was seen with an irrelevant primary antibody (anti-HRP) at an 

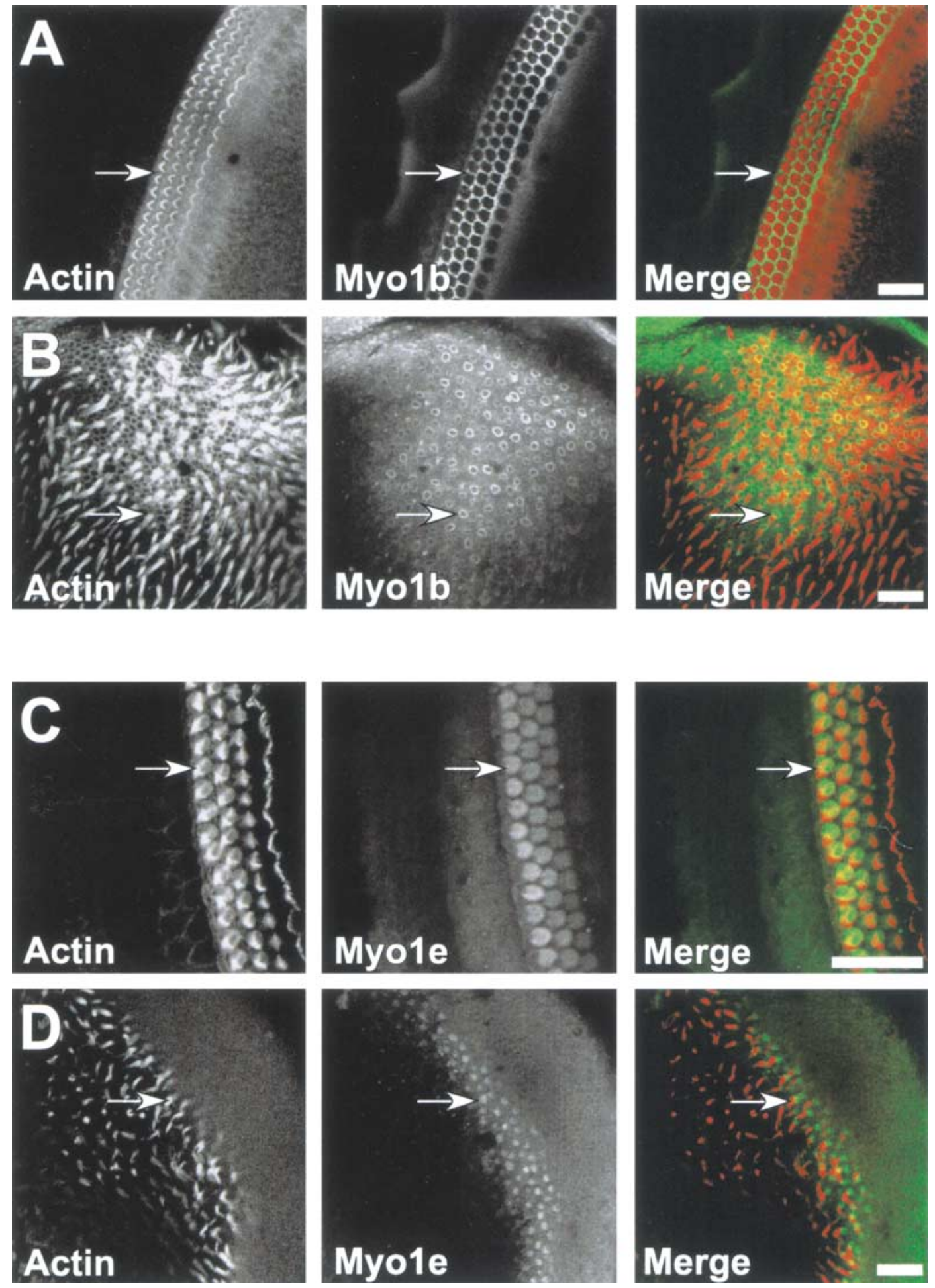

Fig. 5. Immunofluorescence localization of Myo1b and Myo1e in rat cochlea and vestibular organs. Left columns, FITC-phalloidin; middle columns, antimyosin antibody; right columns, merged phalloidin (red) and antibody (green). A. Myo1b immunolabeling using the Tü 30 antibody in P1 rat cochlea; arrow: labeling surrounding outer hair cell. B. Myo1b immunolabeling using the Tü 30 antibody in P1 rat utricle; arrow: labeling in rings associated with circumferential actin belts. C. Myo1e immunolabeling using the FML 6 antibody in P1 rat cochlea; arrow: labeling in outer-hair-cell cuticular plate. D. Myo1e immunolabeling using the FML 6 antibody in P1 rat utricle. Arrow: labeling in cuticular plate. Scale bars, $25 \mu \mathrm{m}$. 
TABLE 3

\begin{tabular}{|c|c|c|c|c|c|c|c|c|c|c|c|c|}
\hline \multirow[b]{3}{*}{ Structure } & \multicolumn{8}{|c|}{ Myosin-I localization in rodent inner-ear epitheliaa } & \multirow{2}{*}{\multicolumn{4}{|c|}{ Myo1e }} \\
\hline & \multicolumn{4}{|c|}{ Myo1b } & \multicolumn{4}{|c|}{ Myo1c } & & & & \\
\hline & PO & $P 7$ & P14 & $P 21$ & PO & $P 7$ & P14 & $P 21$ & PO & $P 7$ & P14 & $P 21$ \\
\hline \multicolumn{13}{|l|}{ Cochlea } \\
\hline Hair bundles & - & - & - & - & $+/-$ & $+/-$ & $+/-$ & $+/-$ & - & - & - & - \\
\hline Cuticular plate & - & - & - & - & $+/-$ & $+/-$ & $+/-$ & $+/-$ & + & + & + & + \\
\hline $\mathrm{ZA}$ ring & - & - & - & - & - & - & - & - & - & - & - & - \\
\hline Hair-cell body & - & - & - & - & $+/-$ & $+/-$ & $+/-$ & $+/-$ & $+/-$ & $+/-$ & $+/-$ & $+/-$ \\
\hline Supporting-cell apices & ++ & - & - & - & - & - & - & - & - & - & - & - \\
\hline Supporting-cell bodies & - & - & - & - & - & - & - & - & - & - & - & - \\
\hline \multicolumn{13}{|l|}{ Utricle and saccule } \\
\hline Hair bundles & - & - & - & - & + & + & + & + & - & - & - & - \\
\hline Cuticular plate & - & - & - & - & - & - & - & - & + & + & + & + \\
\hline ZA ring & ++ & ++ & - & - & - & - & - & - & - & - & - & - \\
\hline Hair-cell bodies & - & - & - & - & - & - & - & - & $+/-$ & $+/-$ & $+/-$ & $+/-$ \\
\hline Supporting-cell apices & $+/-$ & - & - & - & - & - & - & - & - & - & - & - \\
\hline Supporting-cell bodies & - & - & - & - & - & - & - & - & - & - & - & - \\
\hline
\end{tabular}

identical concentration. In addition, Myolc immunoreactivity can be more robust if fixation is avoided (Gillespie et al. 1993; Steyger et al. 1998). We therefore carried out immunocytochemistry with the R2652 antibody on unfixed, purified hair bundles. Myolc immunoreactivity was much greater than control immunoreactivity (not shown) and was focused in a punctate fashion near stereocilia tips (Fig. $6 \mathrm{M}, \mathrm{N})$. Taken together, these diverse Myolc immunolabeling experiments demonstrated that rodent cochlear and vestibular hair cells express Myo1c and that, at least in the vestibular system, it is concentrated at stereociliary tips.

\section{Myo1c tail-GFP localization in hair cells}

We generated an adenovirus vector (Ad-GFP::T698) that carried the gene for GFP fused, in frame, to the tail domain of Myolc (amino acids 698-1028). To confirm targeting of Myolc to stereociliary tips, we infected cultured hair cells of the mouse utricle with Ad-GFP::T698. GFP::T698 was targeted to hair-cell membranes, unlike GFP alone (Holt et al. 1999); in addition, levels were high in the hair bundle (Fig. 7AD). Although we expected higher bundle fluorescence intensity because of the greater density of membrane in a confocal section, the fluorescence intensity was often particularly high at stereociliary tips (Fig. 7E,F). Tip labeling was only seen early (10$12 \mathrm{~h}$ ) after infection; as the expression of the fusion protein increased $(>24 \mathrm{~h}$ postinfection), GFP fluorescence patterns spread uniformly throughout the entire bundle.

\section{DISCUSSION}

Neonatal mouse utricle for molecular characterization of hair-cell transduction

Identifying the molecules responsible for mechanotransduction by hair cells has proven exceptionally difficult, in part because hair cells' scarcity has prevented straightforward biochemical and molecular biological experiments. Until recently, the experimental system best suited for molecular characterization of hair-cell transduction has not been obvious. The evidence provided here and elsewhere (Holt et al. 1997, 1999) suggests strongly that the neonatal mouse utricle is an excellent preparation. Prominent reasons for choice of this organ include the following: (1) Many mouse ESTs have been sequenced, and the mouse genome will soon be sequenced in its entirety. (2) Foreign genes can be expressed in mouse hair cells using conventional transgenic (Boeda et al. 2001), bacterial artificial chromosome transgenic (Zuo et al. 1999), or adenovirus (Holt et al. 1999) methodologies. (3) Endogenous genes of the mouse can be targeted for deletion or subtle mutagenesis (Joyner 2000). (4) Hair-cell transduction and adaptation of mouse utricle are relatively easily measured and closely resemble those in bullfrog sacculus, where they have been characterized most thoroughly (Holt et al. 1997). (5) Neonatal auditory and vestibular organs can be cultured for several days to weeks without gross morphological changes, permitting experiments of extended duration (Russell and Richardson 1987; Rusch and Eatock 1996). (6) Many cDNA libraries, DNA probes, and antibodies are available for 

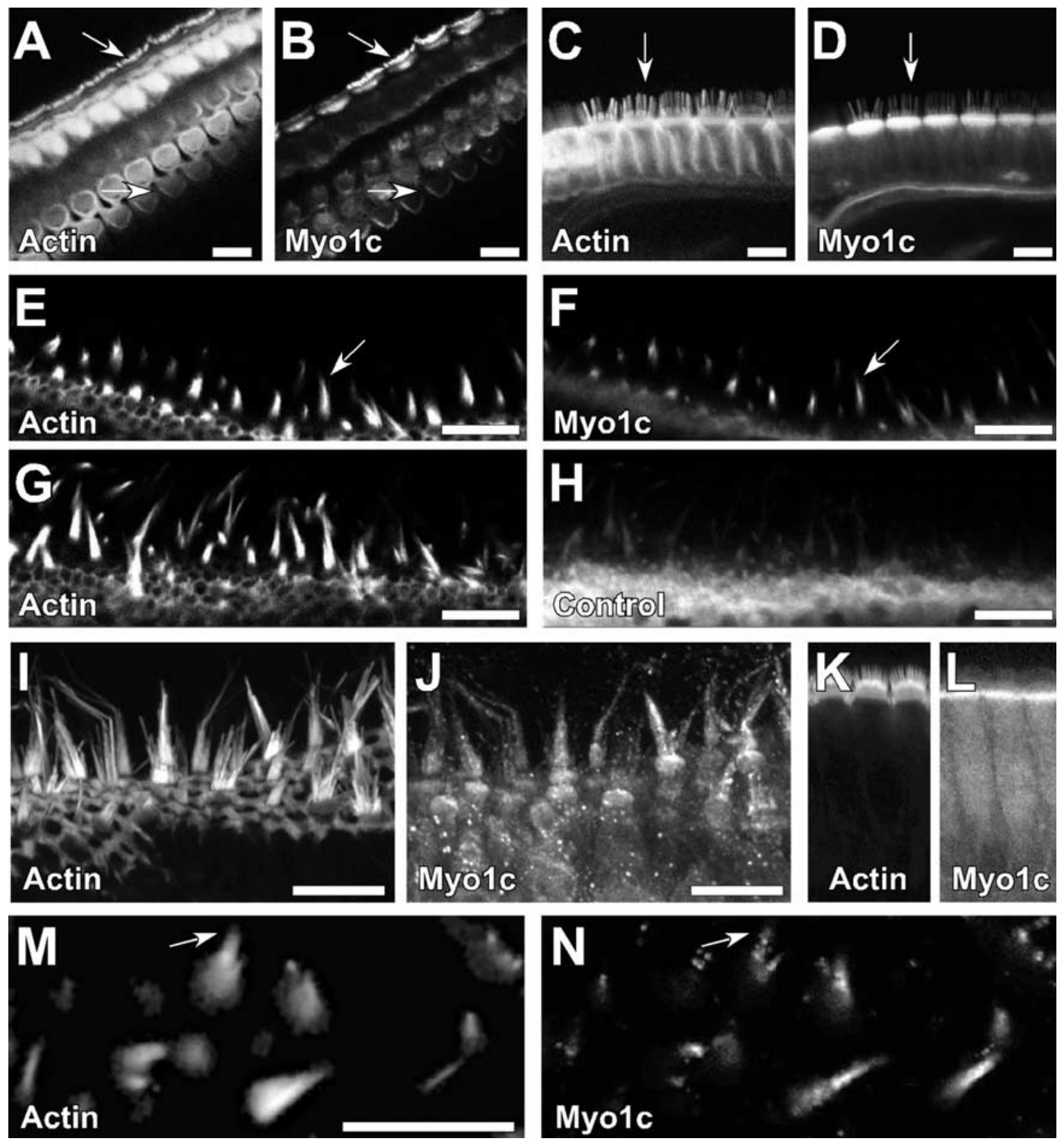

Fig. 6. Immunofluorescence localization of Myo1c in rat cochlea and vestibular organs. A, B. FITC-phalloidin (A) and Myo1c immunoreactivity using the 2652 antibody (B) in P14 rat cochlea. Top arrow: labeling in bundle of inner hair cell. Bottom arrow: labeling in bundle of outer hair cell. C, D. FITC-phalloidin (C) and Myo1c immunoreactivity using the 2652 antibody (D) in P21 rat cochlea. Arrow: labeling in bundle of inner hair cell. E, F. FITC-phalloidin (E) and Myo1c immunoreactivity using the 2652 antibody $(\mathbf{F})$ in P7 rat vestibular organ. Arrow: labeling at tips of hair bundles. G, H. FITCphalloidin $(\mathbf{G})$ and antihorseradish peroxidase immunoreactivity $(\mathbf{H})$

mouse genes, transcripts, and proteins. Here we show that hair bundles can be purified from mouse utricle in reasonable yield, permitting biochemical characterization of bundle proteins.

in $\mathrm{P} 7$ rat vestibular organ. Samples in $\mathrm{E}-\mathrm{H}$ were processed simultaneously. I, J. FITC-phalloidin (I) and Myo1c immunoreactivity using the 2695 antibody (J) in P7 mouse semicircular canal (projections). K, L. FITC-phalloidin (K) and Myo1c immunoreactivity using the 2695 antibody (L) in P7 mouse cochlea (inner hair cells). M, N. FITCphalloidin (M) and Myo1c immunoreactivity using the 2652 antibody $(\mathbf{N})$ in neonatal mouse vestibular hair bundles, purified, and imbedded in agarose. Arrow: note concentration of Myo1c immunoreactivity towards tips. Scale bars in panels, $10 \mu \mathrm{m}$.

The organ of Corti from neonatal mice has been used extensively for characterization of properties of hair-cell transduction. Nevertheless, these hair cells are not fully developed; for example, adult innerva- 

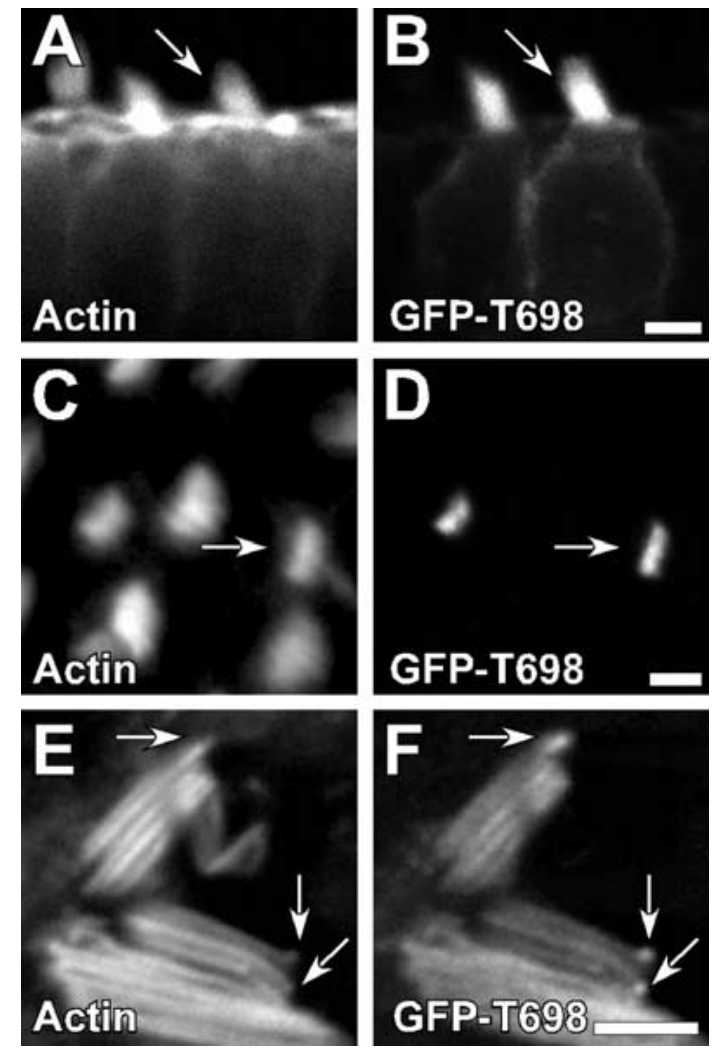

Fig. 7. Expression of GFP-Myo1c tail in mouse utricular hair cells. A, B. Two hair cells, shown in longitudinal section, infected with the GFP::T698 virus for 24 hours, with phalloidin-labeled actin (A) and GFP fluorescence (B). C, D. Two different hair cells, with the optical section near stereociliary tips, infected with the GFP::T698 virus for 24 hours, with phalloidin-labeled actin (C) and GFP fluorescence (D). E, F. Hair bundle viewed from above, infected with GFP::T698 virus for 12 hours, with phalloidin-labeled actin (E) and GFP fluorescence $(\mathbf{F})$, bundle splayed to reveal concentration of fluorescence at tips of individual stereocilia (arrows).

tion patterns are not established until more than three weeks after birth (Sobkowicz 1992), and electromotility, thought to be essential for the sensitive operation of the cochlea, does not appear at full strength until $\sim$ P12 (Belyantseva et al. 2000). Mouse vestibular organs develop more quickly, but still not reach their fully adult form until 2-3 weeks after birth (Desmadryl et al. 1992). Nevertheless, the simplicity of dissection of the neonatal organ-transduction currents are much more easily measured-makes the neonatal mouse organ more suitable for experiments that include testing the normal function of the hair bundle.

\section{Myosin-I isozymes in inner-ear organs}

We observed by RT-PCR expression in mouse utricle all eight myosin-I isozymes. mRNA levels for Myolb, Myolc, and Myole were higher than for the other isozymes; the corresponding three proteins were also expressed at easily detected levels. With the possible exception of Myold, which we detected by immunoblot in rat cochlea, and Myolf, which has been cloned from a cochlear cDNA library (Crozet et al. 1997), expression of the other isozymes may result from basal transcription of genes not expressed at significant levels in the inner ear. Although the sensitivity of RT-PCR permits us to detect exceptionally low levels of mRNA, we suspect that little protein is expressed for each isozyme. Consistent with that interpretation, detection of Myola, Myolg, and Myolh by RT-PCR was sporadic. A possible exception might be if one or more of these isozymes is expressed at a substantial level in a scarce cell type in the inner ear.

Myolb is prominent in auditory and vestibular epithelia for very short periods; this isozyme in each case is associated with apical structures of hair cells or supporting cells. The kinetic mechanism of rat Myolb's actomyosin ATPase has been thoroughly characterized, and its properties suggest that this isozyme is optimized for tension maintenance (Coluccio and Geeves 1999; Veigel et al.1999). We propose that Myolb participates in the relative growth of apical surfaces of hair and supporting cells. Consistent with this interpretation, Myolb is particularly enriched in cellular protrusions of cultured cells, including lamellopodia, membrane ruffles, and filopodia (Ruppert et al. 1995). Indeed, Myolb may participate directly in dynamic properties of motile cells at their leading edges (Tang and Ostap 2001). Notably, apical surfaces of Deiters' cells-the location of Myolb in the organ of Corti-are densely packed with microvilli immediately after birth, but largely lose these microvilli by day 10 ( $\mathrm{Lim}$ and Anniko 1985). If these microvilli are involved in transport of nutrients during organ of Corti development, as are microvilli of the intestinal epithelium, Myo1b may play a role in transport as has been proposed for Myola in the intestine (Skowron and Mooseker 1999).

Myole is localized to cuticular plates of hair cells, which consist of a meshwork of crosslinked actin filaments (DeRosier and Tilney 1989); significantly, rat Myole (myr 3) crosslinks actin filaments (Stoffler and Bähler 1998), suggesting that Myole may share this role in hair cells with Myo6, which has also been proposed to crosslink cuticular-plate actin filaments (Hasson et al. 1997). The ATPase activity of Myole is regulated by its own tail domain, including its $\mathrm{SH} 3$ domain (Stoffler and Bähler 1998), suggesting that a binding partner may control its activity and hence the actin crosslinking properties. In other cells, Myole is concentrated on actin-rich structures containing alpha-actinin (Stoffler et al. 1995); notably, cuticular 
plates of mammalian hair cells contain substantial amounts of alpha-actinin (Slepecky and Chamberlain 1985; Slepecky and Ulfendahl 1992). Although Myole localizes in many cell types to adheren junctions (Stoffler et al. 1995, 1998), we did not observe this isozyme in such junctions of hair cells. We suggest that one role for Myole in hair cells may be to control tension of actin filaments within the cuticular plate, under unknown control.

\section{Myosin-Ic and adaptation}

As in bullfrog sacculus Gillespie and Hudspeth 1993; Metcalf et al. 1994; Solc et al. 1994; Hasson et al. 1997), Myolc is the best candidate for the adaptation motor in rat and mouse utricle. Myole is localized near stereociliary tips, the site of adaptation, and is present in sufficient quantity $(\sim 170$ molecules per stereocilium) to fulfill the need for substantial force generation, minimization of transduction-current noise generated by motor stepping, and continuous attachment (Hudspeth and Gillespie 1994; Gillespie and Corey 1997). These data support our demonstration that inhibition of a nucleotide-sensitized Myolc mutant produces a block of adaptation, strongly implicating Myolc as the adaptation motor (Holt et al. 2001).

All myosin-I isozymes have a highly basic tail segment, which targets myosin to acidic phospholipids. Protein expressed by the T698-GFP adenovirus construct is enriched in hair bundles, perhaps because the bundle is rich in phosphatidylinositol bisphosphate (Tachibana et al. 1984). When expression levels are low, T698-GFP first binds near stereociliary tips; as expression levels rise, the localization domain expands to include the entire hair-bundle membrane. T698-GFP presumably interacts with Myo1c receptors, which should be located at stereociliary tips to organize the adaptation-motor myosins (Gillespie and Corey 1997). As with other myosin isozymes, however, the motor head domain may also be necessary to properly target Myolc (Tang and Ostap 2001).

The role of Myolc in cochlear hair cells is less clear. Although antibodies detected Myolc in inner and outer hair cells, this isozyme was not obviously concentrated at stereociliary tips. Because prominent slow adaptation is generally not apparent in cochlear hair cells (Kros et al. 1992; Geleoc et al. 1997), these hair cells may not require an adaptation motor. Nevertheless, the adaptation motor may play other essential roles besides mediating slow adaptation, including setting the resting tension applied to the transduction channels (Gillespie and Corey 1997; Steyger et al. 1998; Gillespie and Walker 2001). Al- ternatively, maintenance of resting tension may be set in cochlear hair cells by another isozyme, such as myosin-VIIa (Kros et al. 2002).

\section{ACKNOWLEDGMENTS}

We thank Jonathan Berg and Richard Cheney for sharing human Myolg and Myolh sequences and for nomenclature discussions. We also thank Susan Gillespie for comments on the manuscript. This study was supported by NIH grants DC02368 and DC03279. J.R.H. was supported by an NIDCD grant (DC00304) to D.P. Corey, an Investigator with the Howard Hughes Medical Institute. The GenBank accession numbers for sequences reported here are AF426463 (Myo1b), AF426464 (Myold), AF426465 (Myole), AF426466 (Myo1f), AF426468 (Myolg), and AF426467 (Myo1h).

\section{REFERENCES}

ADAms JC. Biotin amplification of biotin and horseradish peroxidase signals in histochemical stains. J. Histochem. Cytochem. 40:1457-1463, 1992.

Altschul SF, Gish W, Miller W, Myers EW, Lipman DJ. Basic local alignment search tool. J. Mol. Biol. 215:403-410, 1990.

Avraham KB, Hasson T, Steel KP, Kingsley, DM, Russell LB. The mouse Snell's waltzer deafness gene encodes an unconventional myosin. Nat. Genet. 11:369-375, 1995.

Bähler M, Kroschewski R, Stoffler HE, Behrmann T. Rat myr 4 defines a novel subclass of myosin I: identification, distribution, localization, and mapping of calmodulin-binding sites with differential calcium sensitivity. J. Cell Biol. 126:375-389, 1994.

Belyantseva iA, Adler HJ, Curi R, Frolenkov GI, Kachar B. Expression and localization of prestin and the sugar transporter GLUT-5 during development of electromotility in cochlear outer hair cells. J. Neurosci. 20:RC116, 2000.

Berg JS, Powell BC, Cheney RE. A millennial myosin census. Mol. Biol. Cell 12:780-794, 2001.

Boeda B, Weil D, Petit C. A specific promoter of the sensory cells of the inner ear defined by transgenesis. Hum. Mol. Genet. 10:1581-1589, 2001.

Burlacu S, TAP WD, Lumpkin EA, HudsPeth, AJ. ATPase activity of myosin in hair bundles of the bullfrog's sacculus. Biophys. J. 72:263-271, 1997.

Coluccio LM. Myosin I. Am. J. Physiol. 273:C347-359, 1997.

Coluccio LM, Geeves MA. Transient kinetic analysis of the $130-\mathrm{kDa}$ myosin I (MYR-1 gene product) from rat liver. A myosin I designed for maintenance of tension? J. Biol. Chem. 274:2157521580, 1999.

Crozet F, El Amraoui A, Blanchard S, Lenoir M, Ripoll C, Vago P, Hamel C, Fizames C, LeVi-Acobas F, Depetris D, Mattei MG, Weil D, Pujol R, Petit C. Cloning of the genes encoding two murine and human cochlear unconventional type I myosins. Genomics 40:332-341, 1997.

DeRosier DJ, Tilney LG. The structure of the cuticular plate, an in vivo actin gel. J. Cell Biol. 109:2853-2867, 1989.

Desmadryl G, Dechesne CJ, Raymond J. Recent aspects of development of the vestibular sense organs and their innervation. In: Romand R (ed) Development of the Auditory and Vestibular Systems 2. Amsterdam, Elsevier, pp 461-487, 1992. 
Drenckhahn D, Engel K, Höfer D, Merte C, Tilney L, Tilney M. Three different actin filament assemblies occur in every hair cell: each contains a specific actin crosslinking protein. J. Cell. Biol. 112:641-651, 1991.

Garcia JA, Yee AG, Gillespie PG, Corey DP. Localization of myosin$\mathrm{I} \beta$ near both ends of tip links in frog saccular hair cells. J. Neurosci. 18:8637-8647, 1998.

Geleoc GS, Lennan GW, Richardson GP, Kros CJ. A quantitative comparison of mechanoelectrical transduction in vestibular and auditory hair cells of neonatal mice. Proc. R. Soc. B Biol. Sci. 264:611-621, 1997.

Gibson F, Walsh J, Mburu P, Varela A, Brown KA, Antonio M, Beisel KW, SteEl KP, Brown SDM. A type VII myosin encoded by the mouse deafness gene shaker-1. Nature 374:6264, 1995.

Gillespie PG, Albanesi JP, Bähler M, Bement WM, Berg JS, Burgess DR, Burnside B, Cheney RE, Corey DP, Coudrier E, et al. Myosin-I nomenclature. J. Cell Biol. 155:703-704, 2001.

Gillespie PG, Corey DP. Myosin and adaptation by hair cells. Neuron 19:955-958, 1997.

GiLlesPIE PG, GiLlesPIE SK. Improved electrophoresis and transfer of picogram amounts of protein with hemoglobin. Anal. Biochem. 246:239-245, 1997.

Gillespie PG, Gillespie SK, Mercer JA, Shah K, Shokat KM. Engineering of the myosin-I $\beta$ nucleotide-binding pocket to create selective sensitivity to $\mathrm{N}^{6}$-modified ADP analogs. J. Biol. Chem. 274:31373-31381, 1999.

Gillespie PG, Hasson T, Garcia JA, Corey DP. Multiple myosin isozymes and hair-cell function. Cold Spring Harb. Symp. Quant. Biol. 61:309-318, 1996.

GiLlespie PG, HudsPeth AJ. High-purity isolation of bullfrog hair bundles and subcellular and topological localization of constituent proteins. J. Cell Biol. 112:625-640, 1991.

Gillespie PG, HudsPeth AJ. Adenine nucleoside diphosphates block adaptation of mechanoelectrical transduction in hair cells. Proc. Natl. Acad. Sci. USA 90:2710-2714, 1993.

Gillespie PG, Wagner MC, Hudspeth AJ. Identification of a 120 kd hair-bundle myosin located near stereociliary tips. Neuron 11: 581-594, 1993.

Gillespie PG, WALker RG. Molecular basis of mechanosensory transduction. Nature 413:194-202, 2001.

Hasson T, Gillespie PG, Garcia JA, MacDonald RB, Zhao Y, Yee AG, Corey DP. Unconventional myosins in inner-ear sensory epithelia. J. Cell Biol. 137:1287-1307, 1997.

Holley MC, Kalinec F, Kachar B. Structure of the cortical cytoskeleton in mammalin outer hair cells. J. Cell Sci. 102:569-580, 1992.

Holt JR, Corey DP, EATOCK RA. Mechanoelectrical transduction and adaptation in hair cells of the mouse utricle, a low-frequency vestibular organ. J. Neurosci. 17:8739-8748, 1997.

Holt JR, Gillespie SKH, Provance DW, Shah K, Shokat KM, Corey DP, Mercer JA, Gillespie PG. A chemical-genetic strategy demonstrates myosin 1c mediates adaptation by hair cells. Cell 108:371-381 2002.

Holt JR, Johns DC, Wang S, Chen ZY, Dunn RJ, Marban E, Corey DP. Functional expression of exogenous proteins in mammalian sensory hair cells infected with adenoviral vectors. J. Neurophysiol. 81:1881-1888, 1999.

Hudspeth AJ, Gillespie PG. Pulling springs to tune transduction: adaptation by hair cells. Neuron 12:1-9, 1994

Joyner AL. Gene Targeting: A Practical Approach. Oxford, Oxford University Press, 2000.

Kros CJ, Marcotti W, van Netten SM, Self TJ, Libby RT, Brown SDM, Richardson GP, Steel KP. Reduced climbing and increased slipping adaptation in cochlear hair cells of mice with mutations in the Myo7a gene. Nat. Neurosci. 5:41-47, 2002.
Kros CJ, Rüsch A, Richardson GP. Mechano-electrical transducer currents in hair cells of the cultured neonatal mouse cochlea. Proc. R. Soc. Lond. B Biol. Sci. 249:185-193, 1992.

Lalwani AK, Goldstein JA, Kelley MJ, Luxford W, Casetelein CM, MHATRE AN. Human nonsyndromic hereditary deafness DFNA17 is due to a mutation in nonmuscle myosin MYH9. Am. J. Hum. Genet. 67:1121-1128, 2000.

Lim DJ, Anniko M. Development morphology of the mouse inner ear. A scanning electron mocroscopic observation. Acta Otolaryngol. Suppl. 422:1-69, 1985.

Metcalf AB, Chelliah Y, Hudspeth AJ. Molecular cloning of a myosin I $\beta$ isozyme that may mediate adaptation by hair cells of the bullfrog's internal ear. Proc. Natl. Acad. Sci. USA 91:1182111825, 1994.

O'Reilly DR, Miller LK, Luckow VA. Baculovirus Expression Vectors: A Laboratory Manual. New York, Oxford University Press, 1994.

Probst fJ, Fridell RA, Raphael Y, Saunders Tl, Wang A, Liang Y, Morell RJ, Touchman JW, Lyons RH, Noben-Trauth K, FriedMAN TB, CAMPER SA. Correction of deafness in shaker-2 mice by an unconventional myosin in a BAC transgene. Science 280:1444-1447, 1998.

Ruppert C, Godel J, Muller RT, Kroschewsis R, Reinhard J, Bähler M. Localization of the rat myosin I molecules myr 1 and myr 2 and in vivo targeting of their tail domains. J. Cell Sci. 108:37753786, 1995.

RupPERT C, KRosChewski R, BÄHLER M. Identification, characterization and cloning of myr 1, a mammalian myosin-I. J. Cell Biol. 120:1393-1403, 1993.

Rusch A, EATOCK RA. A delayed rectifier conductance in type I hair cells of the mouse utricle. J. Neurophysiol. 76:995-1004, 1996.

Russell IJ, RichaRdson GP. The morphology and physiology of hair cells in organotypic cultures of the mouse cochlea. Hear. Res. 31:9-24, 1987.

Sherr EH, Joyce MP, Greene LA. Mammalian myosin $\mathrm{I} \alpha$, I $\beta$, and $\mathrm{I} \gamma$ : new widely expressed genes of the myosin I family. J. Cell Biol. 120:1405-1416, 1993.

SKowron JF, Mooseker MS. Cloning and characterization of mouse brush border myosin-I in adult and embryonic intestine. J. Exp. Zool. 283:242-257, 1999.

SLEPECKY NB, Chamberlain SC. Immunoelectron microscopic and immunofluorescent localization of cytoskeletal and muscle-like contractile proteins in inner ear sensory hair cells. Hear. Res. 20:245-260, 1985.

SLEPECKY NB, UlfENDAHL M. Actin-binding and microtubule-associated proteins in the organ of Corti. Hear. Res. 57:201-215, 1992.

Sobkowicz HA. The development of innervation in the organ of Corti. In: Romand R (ed). Development of the Auditory and Vestibular Systems 2. Amsterdam, Elsevier, pp 59-100, 1992.

Solc CK, Derfler BH, Duyk GM, Corey DP. Molecular cloning of myosins from bullfrog saccular macula: a candidate for the hair cell adaptation motor. Aud. Neurosci. 1:63-75, 1994.

Steyger PS, Gillespie PG, Baird RA. Myosin I $\beta$ is located at tip link anchors in vestibular hair bundles. J. Neurosci. 18:4603-4615, 1998.

StOFfler HE, BäHLER M. The ATPase activity of Myr3, a rat myosin I, is allosterically inhibited by its own tail domain and by $\mathrm{Ca}^{2+}$ binding to its light chain calmodulin. J. Biol. Chem. 273:1460514611, 1998.

Stoffler He, Honnert U, Bauer CA, Hofer D, Schwarz H, MulLer RT, Drenckhahn D, BÄHLer M. Targeting of the myosin-I myr 3 to intercellular adherens type junctions induced by dominant active Cdc42 in HeLa cells. J. Cell Sci. 111:27792788, 1998.

Stoffler HE, Ruppert C, Reinhard J, Bähler M. A novel mammalian myosin I from rat with an SH3 domain localizes to Con A- 
inducible, F-actin-rich structures at cell-cell contacts. J. Cell Biol. 129:819-830, 1995.

Tachibana M, Morioka H, Machino M, Oshima W, Mizukoshi F, Mizukoshi O, Yoshioka T. Localization of triphosphoinositide in the cochlea. An electronmicroscopic immunocytochemical study. Histochemistry 81:157-160, 1984.

TANG N, OstaP EM. Motor domain-dependent localization of Myolb (myr-1). Curr. Biol. 11:1131-1135, 2001.

Viegel C, Coluccio LM, Jontes JD, Sparrow JC, Milligan RA, Molloy JE. The motor protein myosin-I produces its working stroke in two steps. Nature 398:530-533, 1999.
Walker RG, Hudspeth AJ. Calmodulin controls adaptation of mechanoelectrical transduction by hair cells of the bullfrog's sacculus. Proc. Natl. Acad. Sci. USA 93:2203-2207, 1996.

Yamoah EN, GillesPie PG. Phosphate analogs block adaptation in hair cells by inhibiting adaptation-motor force production. Neuron 17:523-533, 1996.

Zuo J, Treadaway J, Buckner TW, Fritzsch B. Visualization of $\alpha 9$ acetylcholine receptor expression in hair cells of transgenic mice containing a modified bacterial artificial chromosome. Proc. Natl. Acad. Sci. USA. 96:14100-14105, 1999. 